\title{
The role of transporters on drug therapy
}

\author{
Ngatidjan* \\ Department of Pharmacology and Therapy, Faculty of Medicine, Universitas Gadjah \\ Mada, Yogyakarta, Indonesia
}

DOI: http://dx.doi.org/10.19106/JMedSci004701201506

\begin{abstract}
Pharmacodynamical studies showed that most drugs elicit their effects by acting on 3 kinds of protein molecules known as receptors, enzymes or transporters. Although their detail properties had not been explained for decades the roles of transporters in drug kinetics and dynamics has been well understood, even have been applied in the therapy. Transporters are classified into 2 major classes, the solute carriers (SLC) and ATP-binding cassette $(A B C)$ families. SLC transporters do not possess ATP binding site property as those of ABC transporters. SLC transporters consist of 3 SLC subfamilies i.e. organic cation transporters (OCTs), organic anion transporters (OATs) and organic anion transporting polypeptides (OATPs). In contrast, $A B C$ transporters require ATP hydrolysis to transport substrate across cell membrane. Human $A B C$-transporters consist of $A B C A 1$ 13, ABCB1-11, ABCC1-12, ABCD1-4, ABCE1, ABCF1-3 and ABCG1-8 subfamily.

Although the originally funtion of transporter is to transport specific physiological substrate such as nutrient, hormone, cytokines, neurotransmitters and other physiological subtances across cell membrane the specificity is not restricted to each substrate. Drugs and other xenobiotics which have structural similarity to the physiological substrates are recognized and transported by the related transporters. The competition of them on transporters therefore may lead to the occurence of drug-drug interactions (DDI) or drugphysiological substrate interaction in the drug-kinetics phase. Many transporters located in the liver, intestinal and renal epithelial cell membranes involve in the transport of endogenous substance or xenobiotics including drugs play important roles as protective barrier. Since transporters also serve as the targets of drug action it is understood that transporters play important role in the pathogenesis of diseases as well as in the drug therapy of diseases.
\end{abstract}

\section{ABSTRAK}

Penelitian farmakodinamik menunjukkan bahwa kebanyakan obat menimbulkan efek melalui aksinya pada 3 tempat aksi obat berupa berbagai molekul protein yaitu reseptor, enzim dan transporter. Meskipun sudah puluhan tahun karakteristik transporer belum dapat diterangkan secara rinci tetapi perannya dalam kinetika dan dinamika obat di dalam tubuh telah diketahui dan bahkan telah dipakai sebagai dasar terapi obat. Transporter dapat dibagi menjadi 2 kelompok yaitu keluarga solute carriers (SLC) dan ATP-binding cassette (ABC). Dalam kerjanya transporter SLC tidak melibatkan ATP seperti pada transporter ABC. Transporter SLC terdiri atas 3 subfamili, organic cation transporters (OCTs), organic anion transporters (OATs) dan organic anion transporting polypeptides (OATPs). Berbeda dari SLC transporter ABC membutuhkan hidrolisis ATP dalam mengangkut substrat melewati membran sel. Transporter $A B C$ terdiri atas 8 subfamili yaitu ABCA1-13, ABCB111, ABCC1-12, ABCD1-4, ABCE1, ABCF1-3 dan ABCG1-8.

\footnotetext{
* corresponding author: ngatidjansp@gmail.com
} 
Meskipun secara fisiologis transporter berfungsi mengangkut zat (senyawa) fisiologis tertentu seperti nutrien, hormon, sitokin, neurotransmitor dan senyawa fisiologik lain melewati membran sel dan bersifat spesifik untuk transporter terkait tetapi spesifitas tersebut tidak mutlak. Obat dan zat asing lainnya yang punya kemiripan struktur dengan zat fisiologis sebagai substrat transporter tertentu dapat dikenali dan diangkut oleh transporter itu. Oleh karena itu kompetisi di antara zat-zat itu pada transporter yang sama dapat memunculkan interaksi antara obat satu dengan lainnya atau antara obat dengan zat fisiologik tertentu pada fase kinetika obat. Transporter yang terdapat pada membran sel hepar, epitel usus dan ginjal yang terlibat dalam transportasi senyawa endogen atau zat asing lain seperti obat dapat berperan sebagai sawar untuk organ tertentu. Karena transporter juga merupakan tempat aksi obat maka transporter punya peranan sangat penting dalam patogenesis penyakit tertentu dan terapinya dengan obat.

Keywords: drug transporters - solute carries - ATP-binding cassette - organic cation transporters - organic anion transporting polypeptides

\section{INTRODUCTION}

Pharmacodynamical studies during the last century revealed that most drugs may elicit their effects by acting on 3 kinds of protein molecules known as receptors, enzymes or transporters. Although the details of the mechanism of action had not been explained for decades the roles of transporters in drug translocation (absorption, distribution and excretion) have been known even have been applied in the therapy. The use of reserpine in the therapy of hypertension to inhibit noradrenaline biosynthesis (through an inhibition of dopamine uptake into vesicles in the sympathetic nerve ending) and the use of probenecid to inhibit kidney tubular penicillin reabsorption are the examples of the involvements of transporters in drug pharmacodynamics and pharmacokinetics. In the context of translocation it was also thought for years that the movement of water and small lipid insoluble molecules across cell membrane is simply by slipping in through the small water filled pores of cell membrane..$^{1-3}$ In fact water transportations across the membrane is mediated by aquaporin transporters which are grouped into CHIP (channel forming integral proteins) transporters that generally water selective channels and GLP (aquaglyceroporin) transporters that do not selective to transport water, glycerol and urea. ${ }^{2}$ More attention toward transporters was paid after the discovery of P-glycoprotein (later is known as multi drug resistance, MDR$1)$, the protein which transports anti cancer drug out of cancer cell leads to ineffectiveness of the drug. Transporters also involve in the fail of protease inhibitors to prevent fetal HIV infection in HIV infected pregnant woman who is treated with the drug. ${ }^{4,5}$ It is now understood that transporter is protein molecule located in the cell membrane which plays important roles in the transport of substances across cell membrane, into or out of cells. The primary function of transporter is to cary nutrients and endogenous substances such as sugars, amino acids, sterol, vitamines, hormone and nucleotides across cell membrane. Most transporters found in some tissues or organs such as liver, kidney, intestine, placenta and brain to protect the body from undesired dietary or environmental toxins and drugs..$^{6-8}$ 


\section{DISCUSSION}

\section{Classification of Transporters}

Transporters can be classified into two major classes, the solute carriers (SLC) and ATP-binding cassette (ABC) families. SLC transporters do not possess ATP binding site property as those of $\mathrm{ABC}$ transporters. Some of them utilize an electrochemical difference of substrate transported, known as facilitated or primary transporters. Others SLC transporters utilize an ion gradient across the membrane produced by primary transporters against an electrochemical difference, known as secondary active transporters. ${ }^{6,8,9}$ SLC transporters consist of 3 SLC subfamilies i.e. organic cation transporters (OCTs), organic anion transporters (OATs) and organic anion transporting polypeptides (OATPs). In contrast to SLC, ABC transporters require an ATP hydrolysis to transport substrate across cell membrane. A variety of physiological substances such as sugar, amino acids, peptides, nucleotides, lipids, sterols, bile salts, endogenous metabolites and xenobiotics are transported by these transporters. Drugs that structurally resemble to the substrates are recognized and also transported by these transporters. ${ }^{10}$ The best studied of ABC drug transporters are multi drug resistance (MDR), multi drug resistance associated protein (MRP) and breast cancer resistance protein (BCRP), however most drug transporters belong to the SLC family. ${ }^{6,11}$ It is known that human ABC-transporters consist of ABCA1-13 subfamily, ABCB1-11, ABCC1-12, ABCD14, ABCE1, ABCF1-3 and ABCG1-8..$^{12-14}$ Some of them responsible for the occurrence of drug resistances, they are ABCB1 (MDR1), MRP1-7 (ABCC1-6 and ABCC10), BCRP or ABCG2 transporters. ${ }^{6,10,11,15}$ Transporters are also classified according to the direction of the transfer of substrates mediated by transporters as influx versus efflux transporters, and absorptive versus secretory transporters. Influx transporters transfer substrates into cell where as efflux transporters transfer substrates out of cell. Transporter that drives its substrates into systemic blood circulation is called absorptive transporter, and transporter that transfers substrates from blood circulation into bile, urine or gut lumen is known as secretory transporter. It is therefore, modifications have to be applied for placental and blood brain barrier since in the human body brain and fetus are considered to as isolated compartments. Transporter that facilitates penetration of substrates (physiological substances or drugs) into the brain or fetus is an absorptive transporter although the substrates are transported from blood circulation. Contrary, transporter which transports substrates from the brain or fetus into blood stream is a secretory transporter although it transfers substrates into blood circulation. ${ }^{6}$ It is also thought therefore, that an absorptive transporter does not always mean an influx transporter, and a sectretory transporter does not always an efflux transporter. OAT1 transporter for example, located at the membrane of kidney proximal tubule cell is an influx transporter since it transports drugs from circulating blood into proximal tubule cell then are transported (efflux) leaving proximal tubule cell into urine for elimination. Although it transports drugs into proximal tubule cell however, the OAT1 is a secretory transporter based on its overall roles of removing drugs out of blood circulation. In contrast, OATP-A located at apical membrane of enterocyte which take up (as influx transporter) orally given drug into the cell for their subsequent exit across the basal membrane into blood stream, therefore OATP-A is an absorptive transporter. From the explanation, influx transporter can function 
as either absorptive or secretory transporter depend on the tissue and the membrane domain where they are expressed. ${ }^{6}$ Identified human OATPs consists of OATP1A2, OATP1B1, OATP1B3, OATP1C1, OATP2A1, OATP2B1, OATP3A1, OATP4A1, OATP4C1, OATP5A1, OATP6A1 which are localized in brain, liver, kidney and testis. OATPs identified in mouse and rats are Oatp1a1, Oatp1a2, Oatp1a3, Oatp1a4, Oatp1a5, Oatp1a6, Oatp2a1, Oatp2b1, Oatp4a1, Oatp4c1, Oatp5a1, and Oatp56a1. ${ }^{8}$ Other human SLC transporters consist of OCTs and MATE (multidrug and toxin extrusion) transporters. Expression of human OCT1 and OCT2 are restricted to the liver and kidney respectively while OCT3 is more widely distributed whereas MATEs are predominantly expressed in kidney. ${ }^{16}$ Transporters for water and small lipid insoluble molecules were first identified as channel forming integral proteins (CHIP28) since their molecular weight were $28 \mathrm{kDa}^{17,18}$ and also known as aquaporin-1 (AQP1). Later studies revealed that aquaporin, trasporters for water and other small lipid insoluble molecules can be grouped into CHIP group of aquaporin (AQP0, AQP1, AQP2, AQP4, AQP5, AQP6, and AQP8 transporters) which are generally water channels and GLP (aquaglyceroporin) group transporters (AQP3, AQP7, AQP9, and AQP10) which are not selective for water, glycerol and urea. ${ }^{2}$

\section{Transporters and Pathogenesis of Diseases}

As has been mention before, transporter plays important roles in the transport of nutrients, endogenous substances and xenobiotics including drugs. An abnormality or defect of its nature (structure and other properties) may cause physiological disturbances leads to the occurrence of diseases or causes changes in drug pharmacokinetics leads to the occurrence of drug ineffectivenes or toxicity. Mutations in $\mathrm{ABC}$ transporter genes have been associated to several genetic diseases such as cystic fibrosis, a disease associated with mutation of $\mathrm{ABCC} 7$ or CFTR (cystic fibrosis transmembrane conductance regulator). It consists of an exocrine pancreatic insufficiency, increase of sweat $\mathrm{NaCl}$ content, male infertility and respiratory disease. ${ }^{12,19,20} \mathrm{CFTR}$ is membrane cAMP-activated $\mathrm{Cl}^{-}$channel which is expressed in several tissue including kidney, pancreas, heart, intestine, vas deferens, sweat duct and lung. In the epithelial cells of these organs CFTR mediates the secretion of $\mathrm{Cl}^{-}$, $\mathrm{Na}^{+}$and $\mathrm{K}^{+}$through the channels or anion exchangers, Na-bicarbonate transporters and aquaporin water channels. Mutation in CFTR gene affects the number of channels in the membranes, channel activity and intracellular trafficking of CFTR. Other diseases which also linked to $\mathrm{ABC}$ transporters are DubinJohnson Syndrome (mutations of ABCC2), age-related macular degeneration (ABCA4 mutation), Tangier disease (mutations of ABCA1) and sitosterolaemia which is linked to mutations in ABCG5 and ABCG8. 19,20 ABCA1 transporter is a cholesterol exporter that highly expressed in the liver and tissue macrophages to transport cholesterol, phospholipids and other metabolites from cells to lipid depleted HDL-apolipoproteins initiates formation of HDL particles. ABCA1 therefore, may prevent cardiovascular disease. Other ABC transporters which have the same roles in the prevention of cardiovascular diseases are ABCA7, ABCG1 and ABCG4. ABCA7, a homolog of ABCA1 also selectively transports phospholipids to lipid-depleted apolipoproteins leads to formation of HDL. ABCG1 transporters (in tissue macrophage) and ABCG4 (in brain cells) mediate choletsterol transport from cells to HDL particles. ${ }^{21-23}$ It is recognized 
that mutation of ABCA1 may cause Tangier disease, a rare HDL deficiency syndrome..$^{19,21}$ $\mathrm{ABC}$ transporters now have been associated with a specific disease, progressive familial intrahepatic cholestasis type-2 (PFIC2) caused by mutation of ABCB11 transporter gene leads to lost of its function. ${ }^{6,24}$ The $\mathrm{ABCB} 4$ transporter is also thought to play an important role in the liver since in the absence of ABCB4 the detergent activity of bile salts (transported into bile by ABCB11) solubilize cell membranes leads to biliary toxicity. The evidence indicated that homozygous mutation of ABCB4 causes PFIC3 (progressive familial intrahepatic cholestasis type-3) occures within the first few years of age and characterized by pruritus, jaundice and growth restriction. It is thought therefore the mutations of ABCB4 is associated with a cholestatic diseases. ${ }^{24} \mathrm{~A}$ side effect of statin as rhabdomyolysis may occurred in genetic abnormal variant of OATP1B1 which is expressed in liver. Abnormality of OATP1B1 may cause an increase of statin blood concentration leads to the occurrence of myopathy. ${ }^{9}$ Other SLC transporters OAT1, which is expressed in renal tubular cells mediates the transportation of many drugs such as digoxin, betalactam antibiotics, nonsteroidal anti-inflammatory drugs and antiviral cidofovir. The use of cidofovir for cytomegalovirus rhinitis in AIDS patient may cause nephrotoxicity due to intensive uptake of the drug by OAT1 transporter. However the toxicity can be prevented by co-administration of probenecid which is also transported by OAT1 transporter leads to a decrease cidofovir renal clearance and its nephrotoxicity effect. ${ }^{25}$

\section{Transporters and Pharmacotherapy}

Although the originally role of transporter is to transport specific physiological substrate across cell membrane the specificity is not restricted to each substrate. Drugs and other xenobiotics which have structural similarity to the physiological substrates therefore are recognized and transported by the related transporters. $^{6-8}$ The competition of them on transporters therefore may lead to the occurence of drug-drug interactions (DDI), or drug-physiological substrate interaction in the drug-kinetics phase. ${ }^{6,8}, 9$ Many transporters located in the liver, intestinal and renal epithelial membrane cells involve in the transport of endogenous substance or drugs play important roles in the tissue selective absorption, distribution and elimination of them but may also play important roles as protective barrier to particular cells or organ. ${ }^{26}$ The transporters therefore may also play roles as the targets of drug action lead to the alteratiom of pathogenesis of diseases and the therapy of diseases. ${ }^{27,28}$ In the therapy of diabetes melitus for example, the use of metformin to decrease blood glucose level is based on the effects of metformin to increase cellular insulin sensitivity lead to the increase of cellular uptake and usage of glucose.${ }^{29}$ Cellular uptake of metformin which is mediated by OCT1 transpoter is increased by rifampin which stimulates pregnane-x receptor to increase hepatocyte OCT1 expression lead to metformin acumulation and increase of its blood glucose lowering effect. Since OCT1 was also observed in subcutaneous and visceral adipose tissue and the OCT1 expression increase in the obese, it is suggested that the mechanism may take account for better effect of metformin in the obese subjects. ${ }^{28}$ It is known that probenecid can increase blood penicillin level since in the excretion process of both drugs are mediated by the same tubular transporter (OAT3) lead to an increase of the effectiveness of penicillin in the therapy. Since methotrexate and antiviral drug adefovir are also transported by OAT3 
it is suggsted therefore to avoid the use of NSAIDs and those drugs in a combination therapy to prevent nephrotoxicicity caused by adefovir. ${ }^{28}$ The use of statin in the therapy of hyperlipidemia and the role of related transporter are extensively studied. OATP1B1 (previously known as OATP-C, OATP-2 and LST-1) found in basolateral membrane of hepatocytes plays important roles in the uptake of statin and OAD (oral antidiabetics). The OATP1B1 is highly polymorphism and $15 \%$ of Asian and Caucasian have abnormal function of OATP1B1 transporter lead to an improper statin uptake. Since the target molecule of statin is 5-hydroxy-3-3-methylglutarylcoenzyme A (HMG-coA) reductase enzyme in the liver, abnormal function of OATP1B1 transporter may cause ineffectiveness of statin therapy in such patient. Is is thought therefore OAD may decrease the lipid lowering effect of statin. ${ }^{26,28}$ Other SLC transporter, OATP2B1 or SLCO2B1 (previously known as OATP-B) found in apical membrane of enterocytes involves in montelukast (a leukotriene receptor antagonist) and aliskiran (found in apple, orange and grapefruit juice) transportation. For that reason, in the therapy of bronchial asthma it is adviced therefore to avoid taking the juice at the same time with the orally montelukast..$^{29} \mathrm{ABC}$ transporters which were identified originally for the ability to extrude anticancer drugs lead to the fail of therapy play important roles in DDI (drugdrug interaction). MDR1 (ABCB1 transporter, P-glycoprotein) is particularly important in the extrude of drugs (such as for digoxin, atorvastatin, HIV-1 protease inhibitors, cyclosporin, verapamil, clarithromycin and talinolol) back into the intestinal lumen and effectively limit the extent of absorption and bioavailability the drugs. Since digoxin is high affinity substrate for intestinal MDR1 it is thought therefore to increase digoxin bioavailability by coadministeration digoxin with the mentioned drugs, or in other hand there must be very careful calculation if such drugs have to be given as a combination with digoxin to prevent digoxin intoxication. ${ }^{27}$ Some $\mathrm{ABC}$ superfamily transporters involve and play important role in drug kinetics and the drugs may be transported by the same transporter. From this viewpoint, again, the use of few drugs in a combination has to be carefully considered, to increase the efficaciousness of therapy as well as to prevent drug toxicity in the other hand. BCRP (ABCG2) transporter which is expreesed in the gastrointestinal tract, liver, kidney, brain epndothelium, mammary tissue, placenta and testis plays roles in limiting certain oral bioavailability and drug transport across blood brain and placental barrier for drugs although the physiological functions of BCRP transporter are the extrusion of porphyrins from haemapoeitic cells and hepatocytes, as well as the secretion of riboflavin (vitamin $\mathrm{B}_{2}$ ), biotin and vitamin $\mathrm{K}$ into breast milk. Subject belong to ABCG2 variant may suffering from drug intoxication such particularly drugs which have narrow therapeutic range. ${ }^{7,26,30}$

\section{CONCLUSION}

Transporters are protein molecules which play important roles in driving substances such as nutrient, neurotransmitters, cytokines and other physiological substances across cell membrane. They are classified into SLC and ABC transporters superfamilies, each transports a specific substarte across membrane cell into (influx) or out of (efflux) the cell. Although the original funtion of transporter is to transport specific physiological substrate, drugs and other xenobiotics which have structural similarity to the substrates are recognized and transported by the related transporters. The competition 
of them on transporters therefore may lead to the occurence of drug-drug interactions (DDI) or drug-physiological substrate interaction in the drug-kinetics phase and alter the pharmacodynamics of the drug.

Since transporters also serve as the targets of drug action it is understood therefore that transporters play important role in the pathogenesis of diseases as well as in the drug therapy of diseases. The understanding of the type, function and distribution of thransporters will increase our ability to predict or make calculation of the effectiveness, efficaciourness and safety of drugs used in the therapy

\section{ACKNOWLEDGEMENTS}

Author would like to thank my colleague Prof. Mustofa who has supported to prepare this review.

\section{REFERENCES}

1. Bowman WC, Rand MJ. Textbook of Pharmacology, 2nd edition. Melbourne: Blackwell Scientific Publication, 1982; 39.1-39.69.

2. Goodman BE. Transport of small molecules across cell membrane: water channels and urea transporters. Adv Physiol Educ 2002; 26(14):146-57. http://dx.doi.org/10.1152/advan.00027.2002

3. Rang HP, Dale MM, Ritter JM, Moore PK. Pharmacology, 5th ed. London-UK: Churchill Livingstone, 2003.

4. Alfirevic A, Park BK, Pirmohamad M. Pharmacogenetic of adverse drug reaction. In: Hall IP, Pirmohamed M. (editors), Pharmacogenetics. New York: Taylor \& Francis, 2006; 65-89. http://dx.doi.org/10.3109/9781420016697-6

5. Cavallari LH, Lam JWF. Pharmacogenetics, In: DiPiro et al. (editors), Pharmacotherapy, a pathophysiological approach. New York: McGraw Hill Co, 2005; 75-90.

6. You G, Morris ME. Overview of drug transporter families, In: Morris ME. (editor) Drug Transporter: molecular characterization and role in drug disposition. New York: John Wiley \& Son In, 2007.

http://dx.doi.org/10.1002/9780470140505.ch1

7. Giacomini KM, Huang SM, Tweedie DJ, Benet $\mathrm{LZ}$, Brouwer $\mathrm{KL}$, Chu $\mathrm{X}$, et al. Membrane transporters in drug development. Nat Rev Drug Discov 2010; 9(3):215-36.

http://dx.doi.org/10.1038/nrd3028

8. Konig J. Uptake transporters of the human OATP family, molecular characteristics, substrates, their role in drug-drug interactions, and functional consequences of polymorphisms, In: Fromm MF, Kim RB. (editors), Drug Transporters. Berlin: Springer-Verlag, 2011; 1-28.

9. Russel FGM. Importance in drug absorption, distribution and elimination, In: Pang KS, et al, (editors), Enzyme and transporter-based drugdrug interaction, New York: American Association of Pharmaceutical Scientists, 2010.

http://dx.doi.org/10.1007/978-1-4419-0840-7_2

10. Sharom FJ. ABC multidrug transporters: structure, function and role in chemoresistance. Pharmacogenomics 2008; 9(1):105-27. http://dx.doi.org/10.2217/14622416.9.1.105

11. Klatt S, Fromm MF, Konic J. Transpoter mediated drug-drug interactions with oral antidiabetic drugs. Pharmaceutics 2011; 3(4):680-705. http://dx.doi.org/10.3390/pharmaceutics3040680

12. Dean M, Hamon Y, Chimini G. The human ATPbinding cassette $(\mathrm{ABC})$ transporter superfamily. J Lipid Res 2001; 42(7):1007-17. http://dx.doi.org/10.1101/gr.gr-1649r

13. Dean M, Rzhetsky A, Allikmets R. The human ATP-binding cassette (ABC) Transporter Superfamily. Genome Res 2001; 11(7):1156-66. http://dx.doi.org/10.1101/gr.GR-1649R

14. Sarkadi B, Homolya L, Szakacs G, Varadi A. Human multidrug resistance $\mathrm{ABCB}$ and $\mathrm{ABCG}$ transporters: participation in a chemoimmunity defense system. Physiol Rev 2006; 86(4):1179236.

http://dx.doi.org/10.1152/physrev.00037.2005

15. Marquez B, Van Bambeke F. ABC multidrug transporters: target for modulation of drug pharmacokinetics and drug-drug interactions. Current Drug Targets 2011; 12(5):600-20. http://dx.doi.org/10.2174/138945011795378504

16. Nies AT, Koepsell H, Damme K, Schwab M. Organic cation transporters (OCTs, MATEs), in 
vitro and in vivo evidence for the importance in drug therapy, In: Fromm MF, Kim RB. (editors), Drug Transporters. Berlin: Springer-Verlag, 2011; 105-67. http://dx.doi.org/10.1007/978-3-642-14541-4_3

17. Goldstein DA, Solomon AK. Determination of equivalent pore radius of human red cells by osmotic pressure measurements. J Gen Physiol 1960; 44:1-17. http://dx.doi.org/10.1085/jgp.44.1.1

18. Preston GM, Carroll TP, Guggino WB, Agre P. Appearance of water channels in Xenopus oocytes expressing red cell CHIP28 protein. Science 1992; 256(5055):385-7. http://dx.doi.org/10.1126/science.256.5055.385

19. van der Deen M, de Vries EG, Timens W, Scheper RJ, Timmer-Bosscha H, Postma DS. ATP-binding cassette (ABC) transporters in normal and pathological lung. Respir Res 2005; 6:59-75. http://dx.doi.org/10.1186/1465-9921-6-59

20. Guggino WB, Stanton BA. New insights into cystic fibrosis: molecular switches that regulate CFTR. Nature Rev Mol Cell Biol 2006; 7(6):42636.

http://dx.doi.org/10.1038/nrm1949

21. Frikke-Schmidt A, Nordestgaard BG, Jensen GB, Tyjaerg-Hansen A. Genetic variation of $\mathrm{ABC}$ transporter A1 contributes to HDL cholesterol in the general population. J Clin Invest 2004; 114(9):1343-53. http://dx.doi.org/10.1172/JCI200420361

22. Heinecke JW, Oram JF. ATP-binding cassette transporter A1: a cell cholesterol exporter that protects against cardiovascular disease. Physiol Rev 2005; 85(4):1343-72.

http://dx.doi.org/10.1152/physrev.00005.2005
23. Yvan-Charvet L, Wang N, Tall AR. Role of HDL, ABCA1 and ABCG1 transporters in cholesterol efflux and immune responses. Arterioscler Thromb Vasc Biol 2010; 30(2):139-43. http://dx.doi.org/10.1161/ATVBAHA.108.179283

24. Nicolaou M, Andress EJ, Zolnerciks JK, Dixon $\mathrm{PH}$, Williamson C, Linton KJ. Canalicular ABC transporters and liver disease. J Pathol 2012; 226(2):300-15. http://dx.doi.org/10.1002/path.3019

25. Han HK. Role of transporters in drug interactions. Arch Pharm Res 2011; 34(11):1865-77. http://dx.doi.org/10.1007/s12272-011-1107-y

26. Brunton LL, Parker KL, Blumenthal DK, Buxton ILO. Goodman \& Gilman's manual of pharmacology and therapeutics. New York: McGraw-Hill Co, 2008; 1-95.

27. Ho RH, Kim RB. Transporters and drug therapy: implication on drug deposition and disease. Clin Pharmachol Ther 2005; 78(3):260-77.

http://dx.doi.org/10.1016/j.clpt.2005.05.011

28. DeGorter MK, Xia CQ, Yang JJ, Kim RB. Drug transporters in drug efficacy and toxicity. Ann Rev Pharmacol Toxicol 2012; 52:249-73.

http://dx.doi.org/10.1146/annurevpharmtox-010611-134529

29. Shu AD, Myers MG, Shoelson SE. Pharmacology of endocrine pancreas, In: Golan et al., (editor) Principles of pharmacology, the pathophysiological basis of drug therapy. Baltimore-USA: Lippicott Williams \& Wolkins, 2008, 31-61.

30. Franke RM, Gardner ER, Sparreboom A. Pharmacogeentics of drug transporters. Curr Pharm Des 2010; 16(2):220-30. http://dx.doi.org/10.2174/138161210790112683 